\title{
The Transferability of Social- and Cultural Anthropology into the Diverse Field of Education in Differing EU Countries
}

Możliwości transmisji antropologii spotecznej i kulturowej do róznych gatęi edukacji w krajach Unii Europejskiej

\section{Introduction}

TRANSCA - Translating Socio-Cultural Anthropology into Education, was an EU project coordinated by the University of Vienna and carried out from September 2018 until August 2020.1 The project's general focus is on providing teachers (and pupils as indirect target group) with novel ways of how to address contested hierarchical structures, which often mark the diversity in the school classes (e.g. minorities within minorities, social class, structural discrimination etc.). The general aim is s to share current practices and new ideas to help anthropology become more widespread in teacher education and consequently, in schools. Pupils are growing up in a highly globalized world, increasingly interconnected

1 Project Partners: Department of Educational Anthropology, Aarhus University, Department of Ethnology and Anthropology, University of Zadar, Communication Centre for Multilingualism, Migration and Human Rights Education, University College of Teacher Education Vienna, Teaching Anthropology Network (EASA), Department of Balkan, Slavic and Oriental Studies, University of Macedonia, Center for Political Education, University College of Teacher Education Vienna. 
by technology, which enhances pupils' need to understand global intercultural dynamics and processes of social inclusion. The overall objectives of the project are the development of innovative didactic strategies, enhancing social inclusion in the educational sphere and thereby sustainably contributing to social cohesion in Europe. The coordinators united relevant academic institutions from four countries (Croatia, Greece and Denmark with Austria taking the lead) represented by lead organizations focused on socio-cultural anthropology (with expertise in teaching anthropology). In addition, the coordinator established cooperation with Teacher Colleges and other relevant institutions as well as multipliers (future teachers and lecturers at teacher colleges) who feedbacked the projects core Intellectual Outputs.

Those so called Intellectual Outputs comprise:

1. a collection of best practice projects focusing on educational anthropology from the following countries: Austria, Switzerland, Germany, Denmark, Sweden, Norway, Greece, Bulgaria, Albania, Croatia, Slovenia, Bosnia and Herzegovina;

2. a concept manual, which provides teachers with key anthropological concepts and methods E relevant for the educational context. These have been selected primarily from the field of anthropology of education and considering their usefulness for reflecting on particular educational questions and issues;

3. new teaching modules for teacher education, aiming at introducing teachers to anthropological approaches and methods in the study of educational lifeworlds and practices. The primary goal is to encourage teachers to explore and reflect upon their professional lives, endeavours and practice in new ways. Ethnography-based didactic approaches are used in these modules as they are apt tools for conveying an understanding of the embeddedness of educational practices in particular and changing cultural, socio-economic and political configurations. Working comparatively with ethnographic cases from different cultural contexts, teachers will explore ways of thinking which make the strange familiar and the familiar strange. (Future) teachers can use these tools for reflecting on the significance, potential, challenges, and constraints of their profession;

4. a whiteboard animation on the topic "worldmaking", accessible via an internet platform functioning as a knowledge database. The platform is available in five languages, and offers users access to methods and networking resources available beyond the end of the funded period of the TRANSCA partnership. 
TRANSCA is a project that tried to demonstrate the importance and usefulness of social anthropology for education. Especially, in regards to the European educational sphere and current endeavours to use education as a response to on-going and new societal challenges such as diversity, immigration, socio-economic disparities and exclusionary politics. The project is a strategic partnership (Erasmus+) aiming to further develop the cooperation between teacher education and socio-cultural anthropology in order to address the crucial issue of social inclusion in schools by implementing e.g. tools for self-reflexivity and hierarchical positionality. It aims to promote, and in some countries initiate, the attempt of transferring concepts and ideas of socio-cultural anthropological knowledge into teacher education in Europe. To achieve these aims, the project builds on existing approaches and experiences and advancing these with new and innovative didactic assessments and practices with regard to core societal issues and social science concepts (such as interculturality, diversity, migration, integration, gender, intersectionality etc.). In this context, the translation of reflexive anthropological projects, methods and approaches into the field of teacher education - such as field excursions, conversation protocols, teacher's (field) diaries - is a core endeavour. We assumed, these would generate ethnographic knowledge and insights of societal challenges that allow teachers to take on the role of a learner, to know their pupils' lived realities in new and substantial ways.

To denominate a project "Translating Social and Cultural Anthropology into Education" (TRANSCA) implies the ability to make anthropological content translatable for a specific target group - in this case people who "teach". The discipline of social and cultural anthropology has a long-standing - not always praiseworthy - tradition of trying to explain and transmit/ translate "knowledge" or "the other" or both. The project team of TRANSCA recurrently asked themselves to what extent this "translation" is possible, but also if and what is getting lost by the aim of this so called translation. So for example, if we try to implement anthropological knowledge into schools, should the idea be that this could happen without anthropologists and does that work? Can readings and exercises convey an anthropological approach? In order to get to the bottom of these questions, the following discussion interrogates the general question of translatability in anthropology and the more specific question of knowledge transfer in educational anthropology. Following the question of how anthropological knowledge can be made accessible to the target group of "teachers" without disguising relationships of power and reproducing a linear idea of transmission.

2 For further information on TRANSCA please visit www.transca.net and https://transca.univie.ac.at. 


\section{Context-dependent and region-specific project}

To start one step earlier: the challenging situation in the TRANSCA project was posed by the fact that in each participating country, educational anthropology has a completely different role.

In the Austrian cultural and social anthropological research tradition the engagement with questions on Education and pedagogy appears to be a rather recent phenomenon. Ethnographic research in educational settings is conducted by social and cultural anthropologists but also by education scientists. Consequently, the number of ethnographic studies dealing with pedagogical and educational questions is much smaller in Austria in contrast to Switzerland and Germany. In addition, none of the departments teaching Cultural and Social Anthropology or European Ethnology has a working group that explicitly focuses on research on and in education. Attempts to foster collaboration between the disciplines as well as between academia and schools have so far been limited to the endeavors of individuals. Slovenia, Croatia and Bosnia and Herzegovina are states that were formed after the dissolution of Socialist Federal Republic Yugoslavia and the countries share a common social and cultural past that have influenced educational systems in all three countries. Across these states the ways of conducting research in educational field, the formation of pedagogical anthropology, educational anthropology and ethnographic inquiry in education as well as including ethnology and anthropology into educational practices differ significantly. However, what they have in common is that anthropology is mostly marginally involved in educational processes. This fact results out of the particularity of ethnology's historical development as a discipline in each of the three countries. In Bosnia and Herzegovina, for example, neither ethnology nor cultural anthropology existed as a field of academic study until 2018.

Likewise, and nonetheless different social anthropology in Greece has gradually received recognition in the classroom as well as beyond the classroom. Ethnography as a research approach has been increasingly popular and important as a conceptual and methodological tool and part of a broad-based scientific training. Moreover, it is incorporated in interdisciplinary undergraduate and postgraduate study programs. Universities have become the main institutions for the transmission of anthropological knowledge and training in ethnographic research methods. It is noteworthy to mention, though, that Pedagogic departments make use of ethnography as a method of study of the school and classroom environment as well as the cultural, social and economic aspects of the current educational context in Greece. Although there are 1-2 anthropology 
positions in Pedagogic departments, anthropology is not included as a subject in teacher education and training in Greece.

A completely different situation appears to be in Denmark where a Masters Program in Anthropology of Education and Globalisation is offered, designed for students seeking advanced training in anthropological approaches to educational practice and process in settings as varied as educational institutions, workplaces and civil society. Using ethnographic research methods and cross-cultural comparisons, the program trains students to analyze specific practices of education and knowledge in relation to local as well as broader (global) social and cultural contexts.

To summarize, historical, national and academic preconditions shaped the TRANSCA project from the start and subsequently led to many discussions about the general notion of translatability in the specific contexts.

\section{The notion of translation for TRANSCA}

The team created an overview of projects implemented in different European regions that may inspire others to develop their own projects with an interface between anthropology and education. The projects were developed through dialogue across regions, critical anthropological reflection and joint conversations with pedagogues, teachers and other practitioners. In the following I will briefly describe three of such projects.

The first example is an interdisciplinary research project, focusing on intercultural learning in multicultural lifeworlds. It was carried out by anthropologists from the University of Vienna, in cooperation with educational specialists, secondary school teachers and 13 year-old pupils in two secondary school classes in Vienna, Austria. The aim was to work with understandings of cultural diversity by familiarising pupils with anthropological concepts and approaches and carrying out mini-field-projects. The project's three phases were spread out over two semesters. Phase one: Social anthropologists, education specialists and secondary school teachers designed a didactic concept - a youth research workshop - to further student competences in relation to cultural heterogeneity. Phase two: A youth research workshop was held where anthropologists taught core anthropological conceptualizations (a.o. gender, age, lifeworld, power) and trained pupils in research techniques (interviewing, participant observation, visual techniques), and scientific methods. Following this, pupils, created, designed and carried out fieldwork on topics concerning their daily lives. Working alone or in small groups, pupils wrote short ethnographies, depicting their lives and understandings of Viennese youth culture. During the second semester, pupils presented their work 
at a junior researchers' congress, held by the University of Vienna This field exercise and ethnographic write-up allowed teachers and pupils to gain more in depth knowledge of the pupils' lifeworlds. Phase three: Researchers and teachers collaborated to integrate insights and findings from the project into school curriculum by developing learning material for pupils aged 10 to 14, and mainly for the subjects of German, Geography and Mathematics (Project JuMuW [You move]).

The second example is from the Moesgaard Museum in Denmark and gives secondary school pupils tools to examine local phenomena from different angles: grasping integration and European politics from the stories of children in an asylum center, colonialism and resource extraction through a photo series from Greenland, or Danish nationalism by attending Sankt Hans bonfires. Allowing pupils to explore how people understand and relate to the world helps them understand how knowledge is forged through experience, observation, conversation, and by collecting objects and pictures. In collaboration with gymnasiums in Mid-Jutland, the project has developed a wide range of teaching materials and concrete exercises specifically designed for use in gymnasiums. Hands-on method exercises train pupils to be curious about the world, while field projects allow them to experience that they too can create knowledge.

The third project in Albania: "Leave No One Behind (LNB)" is a four-year joint UN program supporting the implementation of a new social sector in Albania. It aims to provide vulnerable persons with equal access to public services and opportunities, to help them gain a voice in public decision-making affecting their lives, and to hold public officials accountable. It draws on the technical expertise and know-how of UN agencies to link municipal and national levels. This gives the project a greater impact and outreach. Project objectives are to: 1) empower vulnerable persons, especially persons with disabilities, Roma and Egyptians, and vulnerable women; 2) work toward social inclusion and better access to social services to improve the social situation and well-being of vulnerable categories, and 3) enhance the organizational capacities of municipalities and local social agencies to provide better quality, more inclusive, equitable and efficient services. The project will develop and monitor the implementation and funding of national and NGO policies relevant to social inclusion, social care and protection, gender equality and good governance in Albania.

\section{The contested notion of concepts}

As the writing culture debate (Clifford, Marcus 1986) has shown, it can be doubted whether ethnography as a description of culture, the culture of writing and the construction of culture can trigger more than a "crisis of representation" (Chambers 
2006: 5) suggests for ethnographic writing and linguistic translation "this process is never innocent, but is always embedded in existing power relations" - this also applies to the process of translating supposedly anthropological concepts for another target group (eg teachers). This is probably always the case when someone wants to break down "a concept" to others, as we tried to do in the project.

Another output of the project was to make anthropological concepts accessible - selected on the basis of their usefulness for reflecting on particular educational questions and issues. The project team saw them first and foremost as concepts that are ,helpful for thinking'. For example, the concept of community is useful for thinking about how people understand a particular kind of collectivity - smaller than the nation-state and broader than the family or clan. It may also be useful for thinking comparatively about why there is no term for ,community' in particular language zones (like in Austria for example, where we draw on the english term). There is increasing awareness of how different ways of imagining collectivity influence pedagogical ideas and practices of concepts used. Concomitantly, more attention is paid to the historical and political conditions that have enabled the rise of certain ideas and practices.

Another example is the concept of vulnerable groups, as it refers to social categories of people, usually described as being in a position or a state of helplessness and as lacking the power to cope with a natural or social threat/problem. It is essential for teachers that the term can refer to a diverse group of people comprising children (orphans, separated, street children, associated with disabilities or armed fighting, affected by HIV/AIDS) as well as prisoners, pregnant women, refugees, people with mental ill-health, economically, or educationally disadvantaged. These social categories are often denominated as marginalized persons or groups, rendered invisible to the rest of the society. Critical in conceptualizing the idea of vulnerable groups is the notion of vulnerability. It is a structuring feature of the human condition that is lived and understood in historically shifting circumstances. Vulnerability emerges when unequal social and political forces limit coping capabilities and cause stress that threatens well-being, which then influences modes of resilience, resistance, agency, and adaptability. Global displacement, politico-military polarizations, and recurring environmental and humanitarian crises are seen as causes shaping the experience, distribution, and interpretation of vulnerability (Trundle, Gibson, Bell 2019: 198-199). The idea of vulnerability and groups denominated as such are often associated with a disempowered position. However, encounters with communities, groups and people framed as vulnerable can lead to a disruption between the assumed vulnerability and the actual being of the person as in as 
in a ,traumatized' refugee child, or a child who has lost a parent or sibling to death. The disruption between the imagined/pathologised vulnerability and the actual person is an especially relevant aspect for educational contexts.

The project team was well aware that anthropological concepts cannot simply be translated and introduced uncritically into educational spheres. Such topdown exercises are inherently flawed. Instead, TRANSCA aimed to create, build on and advance an educationally useful interplay of basic research, ethnography, educational anthropology, and educational studies.

Another example for the usage in practice published on the web-platform was the approach of Funds of Knowledge (González 1995: 3) which was originally designed to explore how experiential knowledge, integral to childrens' daily lives, could be utilized in teaching. The "Funds of Knowledge" concept originates from a research project conducted at the University of Arizona (USA) at the end of the 1980s. The starting point of the research project were the socially and pedagogically problematic living conditions in Arizona in the late 1980s (Moll, Amanti, Neff, González 1992). A prevailing climate of negative attributions to minoritized groups (e.g. immigrant) meant that pupils with such a background were also exposed to discriminatory treatment in the school context. In response to such a situation, a group of researchers and educators worked out a counter-proposal based on the knowledge that every household, whether rich or poor, locally-rooted or immigrant, had access to diverse bodies of knowledge (Funds of Knowledge). The project aimed to change teachers' perception of minoritized households. Instead of framing these as educational barriers, teachers should acknowledge them as educational resources for classroom teaching. Teachers accessed pupils' knowledge resources through home visits and qualitative interviews and then designed lessons by building on these insights (González 1995: 3). The original Funds of Knowledge project, discussed in various publications, kicked off a wide range of projects that modified the original approach, adapting it to new local circumstances and needs. TRANSCA found out that The Funds of Knowledge approach is currently (and belatedly) being received and partly implemented in the European context.

However, similar to the transposition of concepts, this approach as a form of translation cannot be seen as a uni-directional process. It will not be enough for teachers to have the "anthropological mindset" accessible through texts. In educational institutions, anthropologists are required to conduct this discussion and to make the reflective way of thinking underlying the concepts understandable. For practitioners it is thus not possible to simply read these concepts and implement them in the educational context. 
What is understood as being education differs massively from region to region and discipline. It is important for anthropologists not just to see teachers and pupils as "the other", who should know more about our discipline, but in addition recognize the contribution pupils and teachers can make to our academic work. Maybe TRANSCA should expand the considerations about the possibility or impossibility of translation drawing on Tim Ingold's idea of "attention":

(...) the word (attention) has a host of related meanings that are equally important for what I shall have to say. These include: caring for people or for things, in a way that is both practical and dutiful; waiting, in the expectation of a call or summons; being present, or coming into presence, as on an occasion; and going along with others, as in joining or accompanying. Besides all these, however, I would like to give an additional meaning to the stretch of life - a temporal one - by which, with bios, life is not merely lived in the here and now but is stretched by a memory of the future that itself allows every present moment to be a new beginning. For this imaginative remembering, or mnemonic imagining, I shall introduce the term 'longing'. Longing, in my usage, is another word for the stretching of a life, along a line (Ingold 2018: 20-21).

Anthropology is a discipline that "pays attention" in many ways - during fieldwork, active listening, comparing, analyzing and many more. There is furthermore not "one" truth in this discipline that is conveyed or the "right" path that can be followed. As irritating as this sometimes is, it could be helpful for any form of education to promote critical, context-specific and participatory learning.

\section{Bibliography}

Chambers, C. (2006). Anthropology as Cultural Translation: Amitav Ghosh's In an Antique Land. Postcolonial Text, 2(3), 5.

Clifford, J., Marcus, G.E. (1986). Writing Culture. The Poetics and Politics of Ethnography. Berkeley: University of California Press.

González, N. (1995). The Funds of Knowledge for Teaching Project. Practicing Anthropology, 17, 3-6.

González, N., Moll, L.C., Amanti, K. (2005). Funds of Knowledge: Theorizing Practices in Households, Communities, and Classrooms. Mahwah-New York: Lawrence Erlbaum Associates.

Ingold, T. (2018). Anthropology and/as Education. New York: Routledge. 
Moll, L., Amanti, C., Neff, D., González, N. (1992). Funds of Knowledge for Teaching: Using a Qualitative Approach to Connect Homes and Classrooms. Theory into Practice, 31, 132-141.

Project JuMuW [You move]): https://www.sparklingscience.at/en/projects/show. html?--typo3_neos_nodetypes-page\%5Bid\%5D=395.

TRANSCA - Translating Socio-Cultural Anthropology into Education: https://www.transca.net.

Trundle, C., Gibson, H., Bell, L. (2019). Vulnerable Articulations: the Opportunities and Challenges of IIIness and Recovery. Anthropology \& Medicine, 26(2), 197-212.

\section{Summary}

This paper discusses the EU project TRANSCA - Translating Socio-Cultural Anthropology into Education. The project shares current practices and ideas to help anthropology become more widespread in teacher education and subsequently, in schools. The paper questions selected concepts (e.g. Funds of Knowledge) and the intentions of translating anthropological knowledge for educational purposes because of the problematic notion of „translation” itself in anthropology.

Key words: education, translation, Europe

\section{Streszczenie}

W artykule omówiony jest unijny projekt TRANSCA - Translating Socio-Cultural Anthropology into Education (Transmisja antropologii społeczno-kulturowej do systemu edukacji). Projekt stanowi platformę wymiany koncepcji i praktyk służących upowszechnieniu antropologii w kształceniu nauczycieli, a następnie także w nauczaniu szkolnym. Wybrane pojęcia (np. fundusze wiedzy) oraz intencje, jakie kryją się za transmisją wiedzy antropologicznej dla potrzeb edukacji, poddane są krytycznej analizie ze względu na problematyczność samego pojęcia „transmisji” w antropologii.

Słowa klucze: edukacja, transmisja, Europa 